\section{Evaluation of Bacillus sphaericus bioinsecticide produced with white soybean meal as culture medium for the control of Culex (Culex) quinquefasciatus}

\author{
Avaliação do bioinseticida de Bacillus sphaericus, \\ produzido com meio de cultivo de farelo branco \\ de soja no controle de Culex (Culex) \\ quinquefasciatus
}

André L. A. Melo 1 Carlos R. Soccol 2 Vanete Thomaz-Soccol 3 Miodeli Nogueira Jr. 4

\footnotetext{
1 Universidade Paranaense, Francisco Beltrão, Brasil.

2 Programa de Pós-graduação em Processos Biotecnológicos, Universidade Federal do Paraná, Curitiba, Brasil. 3 Programa de Pós-graduação em Microbiologia, Parasitologia e Patologia Universidade Federal do Paraná, Curitiba, Brasil. ${ }^{4}$ Programa de Pós-graduação em Zoologia, Universidade Federal do Paraná, Curitiba Brasil.

Correspondence A. L. A. Melo Universidade Paranaense. Rua Padre Agostinho 2715, apto. 135, Curitiba, $P R$ 80710-390, Brasil. andre@unipar.br
}

\begin{abstract}
Bioinsecticides are shown to be useful in control programs to prevent several diseases, based on their specificity and efficiency against insect vectors. In the current study a bioinsecticide based on Bacillus sphaericus was produced using $a$ white soybean culture medium and applied to larvae of Culex quinquefasciatus, the susceptible species, and Aedes aegypti, the refractory species used as the negative control. Efficacy was compared with that of the product fermented with the Luria Bertani (LB) reference medium. The experiments showed that $\mathrm{C}$. quinquefasciatus was highly susceptible to the product prepared with white soybean meal, reaching $100 \%$ larval mortality even at $10 \mathrm{mg} / \mathrm{L}$, while A. aegypti failed to reach $70 \%$ mortality at a concentration of $1 \mathrm{~g} / \mathrm{L}$. By comparison with the reference medium, the proposed culture medium showed high larvicidal power, reaching a $L D 90$ of $2.26 \mathrm{mg} / \mathrm{L}$, while $4.37 \mathrm{mg} / \mathrm{L}$ was needed for the $L B$ medium to achieve the same mortality rate. Cost comparison between the formulations favored the use of the bioinsecticide produced with white soybean meal. After factoring in the LD90 value, the cost ratio favored the new raw material by nearly 1:220.
\end{abstract}

Insecticides; Vector Control; Soybeans
Mosquitoes from the Culicidae family cause various kinds of direct and indirect harm to public health worldwide. In addition to bothering and irritating humans and other animals, provoking a drop in work productivity and livestock production, many species transmit pathogenic agents. In humans alone, microorganisms that cause serious diseases like malaria, dengue, yellow fever, filariasis, and arbovirus infections are transmitted during the blood meals of these insects, resulting in periodic outbreaks in the populations of various countries $1,2,3$. One of the principal factors in the extensive dissemination of some of these insects is their high capacity to reproduce in urban environments, acquired during their long history of co-evolution with the human species. This potential is clearly observed in Aedes (Stegomyia) aegypti Linnaeus, 1762 and Culex (Culex) quinquefasciatus Say, 1823, both highly anthropophilic Culicidae species that reproduce mainly in artificial breeding sites 4 .

For many years, campaigns to combat mosquitoes were based on spraying chemical insecticides both to control larvae and kill adult insects. The initial results of this strategy proved quite satisfactory, leading to the control of various culicid-borne epidemics, especially in the early $20^{\text {th }}$ century ${ }^{5}$. However, after several decades, the consequences of this approach proved quite harmful. Due to the insecticides' high residual power, the persistence of chemical compounds in the environment affects the entire food chain, 
reaching humans themselves 6 . Over time, mosquitoes also developed resistance to chemical insecticides, thus undermining this control strategy's efficacy. Therefore, in recent years the use of organophosphate and organochlorine insecticides has been reduced, while their efficiency has been challenged 7,8. Within this scenario, biological control based on endotoxin-producing bacteria like Bacillus thuringiensis var. israelensis Barjac, 1978 and B. sphaericus Neide, 1904, has proven effective in controlling insect vectors. These bacilli have the advantage of being safe to non-target organisms and non-accumulative in the food chain 9, and are thus considered environmentally safe by the World Health Organization (WHO) 10.

B. sphaericus is an aerobic bacteria that produces a round spore in the terminal portion of its cell. Two types of proteins, crystal toxins and Mtx toxins, produce the larvicidal effect by acting on specific receptors in the midgut of culicid larvae, causing a lethal cytopathological effect 11. Despite its high toxicity, B. sphaericus is very specific, affecting only a small number of susceptible species 12. Another important factor is the bioinsecticide's capacity to recycle itself in dead Culicidae larvae, resulting in greater persistence and greater larvicidal effect by the product 13 . Based on such characteristics, B. sphaericus bioinsecticides are indicated for combating lymphatic filariasis, West Nile fever, 3 and malaria 14 , among other diseases.

In fermentations, $B$. sphaericus is considered an undemanding bacterial species, not requiring differential or selective culture media. Neither does it depend on special conditions to develop. Studies have already shown that a conventional aeration system is sufficient to satisfactorily ensure a good growth rate, sporulation, and formation of larvicidal toxin 15.

Still, although B. sphaericus is cultured using a simple technique, common to other microorganisms, the Luria Bertani (LB) medium reported in the literature for producing the bacteria is relatively expensive, since it requires high-cost laboratory ingredients. This leads to a significant increase in the bioinsecticide's cost, acting as a disincentive to its use on a large scale. In order to reduce the production costs and make the product more accessible to countries that suffer the most from culicid-borne diseases, several authors have suggested implementing local production of bioinsecticides, prioritizing the use of readily available, low-cost local substances 16,17,18.

Around the world, various agricultural products used to culture B. sphaericus have been tested successfully, based on seeds, vegetable extracts, and animal products $16,17,18$. In addition to the nutritional qualities needed for bacterial growth, the raw material must be widely available and cannot require any sophisticated or high-cost extraction or purification process, which would increase the product's end price and reduce its feasibility 15 .

In the current study, we chose to produce a B. sphaericus bioinsecticide using a culture medium with white soybean meal as the base. The bioinsecticide was applied to L4 larvae of C. quinquefasciatus, the most susceptible species to the bacteria, and A. aegypti, the most resistant species, used as the negative control. The product's performance was assessed using mean larval mortality in a bioassay, together with the final price of the bioinsecticide's raw materials compared to the LB reference medium.

\section{Material and methods}

\section{Bioinsecticide production}

The B. sphaericus reference strain 2362 was kindly provided by Dr. Christina Nielsen Le-Roux of the Pasteur Institute, Paris, France.

The culture medium proposed in the current study was prepared with $40 \mathrm{~g} / \mathrm{L}$ of white soybean meal, a soybean byproduct widely used as a supplement in animal feed. The soybean cake was initially ground in a grinder and separated with a sieve with 35-mesh granulometry. Distilled water was added to the medium and the $\mathrm{pH}$ was adjusted to 7.0 adding a $10 \% \mathrm{NaOH}$ solution.

The LB culture medium was prepared according to the usual formula published in the literature 19 for B. sphaericus fermentations. Briefly, the medium consists of peptone, yeast extract, and sodium chloride at a proportion of 2:1:2. In the current study, distilled water was added to the medium and the $\mathrm{pH}$ was adjusted to 7.2 by adding a $10 \% \mathrm{HCl}$ solution.

Using lyophilized samples of B. sphaericus (strain 2362), the microorganism was inoculated in the LB medium and fermented at $30^{\circ} \mathrm{C}$ for 24 hours. It was then divided into small aliquots and stored in a freezer at $-4{ }^{\circ} \mathrm{C}$, with $10 \%$ glycerin at a proportion of $1 / 3$. The flask that was to serve as the inoculum consisted of $150 \mathrm{~mL}$ of the culture medium, either LB or soybean meal, fermented for 24 hours at $30^{\circ} \mathrm{C}$. Next, the fermentations were performed in a $2 \mathrm{~L}$ lab bench bioreactor, which received a volume of 1.5L. For each preparation, the media were sterilized in an autoclave at $120^{\circ} \mathrm{C}$ for 20 minutes. The volumes were shaken at $200 \mathrm{rpm}$, with an aeration rate of $1 \mathrm{v}$ of air per volume of medium. For the soybean meal culture medium, $2 \mathrm{~mL}$ of polyethylene glycol were added 
and the fermentation lasted 72 hours. The LB medium fermentation did not receive any antifoaming agent, and also lasted 72 hours. For the current study, the fermentations were repeated three times on different days to ensure greater data accuracy.

\section{Mosquitoes}

A. aegypti and C. quinquefasciatus larvae were obtained from colonies maintained in the Molecular Parasitology Laboratory at the Federal University in Paraná, Paraná State, Brazil. A. aegypti eggs came from a reference strain from the Pasteur Institute and C. quinquefasciatus larvae were from the Brazilian Army Institute, Rio de Janeiro, Brazil. For rearing the colonies, the adults were kept in cages $(25 \mathrm{~cm} \times 25 \mathrm{~cm})$ coved with screens and maintained in an environmental chamber at $28^{\circ} \mathrm{C}$. The adults were fed with an apple slice approximately $2 \mathrm{~cm}^{2}$ thick and $4 \mathrm{~cm}$ long, changed weekly. The blood meals also occurred weekly, using newborn mice. A. aegypti oviposition was done on filter papers inserted inside recipients with water $(6 \mathrm{~cm} \times 6 \mathrm{~cm})$. The larvae were maintained in plastic trays $(10 \mathrm{~cm} \times 25 \mathrm{~cm})$ with approximately $400 \mathrm{~mL}$ of dechlorinated water, changed every three days. They were fed fish food ad libitum (Alcon Ind. e Com. de Alimentos Desidratados Alcon Ltda., Camboriú, Brazil).

\section{Bioassays}

The bioassays were performed in the same laboratory, based on the model recommended by WHO for experiments with the bacteria 20 .

The tests took place in plastic recipients $10 \mathrm{~cm}$ wide by $10 \mathrm{~cm}$ high, containing a total of twen-

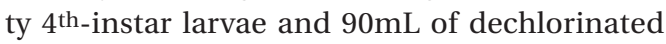
water. The volume was completed to $100 \mathrm{~mL}$ by adding $10 \mathrm{~mL}$ of the diluted bioinsecticide. The different concentrations of bioinsecticide were obtained from $1 \mathrm{~g}$ of the recently fermented product, which was weighed and received volumes of water according to the scheduled dilutions.

The first bioassay was to confirm the specificity of the B. sphaericus bioinsecticide's action, applying it to C. quinquefasciatus and A. aegypti. Seven different dilutions of the product were used for this purpose: $1 \mathrm{~g} / \mathrm{L}, 200 \mathrm{mg} / \mathrm{L}, 100 \mathrm{mg} / \mathrm{L}, 50 \mathrm{mg} /$ $\mathrm{L}, 20 \mathrm{mg} / \mathrm{L}, 10 \mathrm{mg} / \mathrm{L}$, and $5 \mathrm{mg} / \mathrm{L}$. The second bioassay aimed to quantitatively compare the efficiency of the bioinsecticide produced with the medium made of white soybean meal and that of the LB reference medium. Five different dilutions of the product were used: $10 \mathrm{mg} / \mathrm{L}, 4 \mathrm{mg} / \mathrm{L}$, $2 \mathrm{mg} / \mathrm{L}, 1 \mathrm{mg} / \mathrm{L}$, and $0.5 \mathrm{mg} / \mathrm{L}$. The bioinsecticides were applied to the recipients containing the lar- vae, and the larval mortality rates were measured after 48 hours. The tests were performed in triplicate for each dilution, and three control recipients were prepared simultaneously, that is, with the same size and amount of larvae, but without receiving any dose of the fermented product. All the containers received a feed supply, and at the end of the target period the dead larvae were counted. The larval mortality rate was calculated and corrected by the Abbott formula 21. If larval mortality exceeded $20 \%$ in the control flasks, the assay was invalidated. In the second bioassay, the $\mathrm{LD}_{50}$ and $\mathrm{LD}_{90}$ values were calculated by sigmoid adjustment using the Origin 5.0 software (Microcal Software, Massachusetts, USA). To detect significant differences in the efficiency of the two culture media (LB and soybean meal), we used the Student's t test for each dilution. All the tests were performed with a $95 \%$ confidence interval, $\alpha=0.05$.

\section{Results and discussion}

In the first test, at a concentration of $5 \mathrm{mg} / \mathrm{L}$, the bioinsecticide cultured in white soybean meal produced $87.4 \%$ mortality for C. quinquefasciatus larvae, and $100 \%$ at the other concentrations, as shown in Figure 1. The product failed to show a similar performance with $A$. aegypti, with a much weaker effect at all the dilutions. The efficiency was observed to be dose-dependent, but still much lower than with C. quinquefasciatus, confirming the product's specificity for the latter culicid.

During the second stage, the performance of the proposed bioinsecticide was compared to that of the reference medium from the literature. Tested in C. quinquefasciatus larvae, the mortality results for the products fermented with white soybean meal and LB varied according to the concentration (Figure 2).

Based on the findings, both formulations showed high efficiency at the first dilution, but the white soybean medium performed better starting at $4 \mathrm{mg} / \mathrm{L}$ (Figure 2). The white soybean medium performed significantly better at the next three concentrations as compared to the LB medium ( $t$ test; $\mathrm{p}<0.05$ ). Likewise, the $\mathrm{LD}_{50}$ and $\mathrm{LD}_{90}$ clearly favored the white soybean medium, as shown in Table 1. When applied to C. quinquefasciatus L4 larvae, the bioinsecticide cultured in white soybean produced an $\mathrm{LD}_{50}$ of $0.90 \mathrm{mg} / \mathrm{L}$ and an $\mathrm{LD}_{90}$ of $2.26 \mathrm{mg} / \mathrm{L}$.

The LB medium did not show a similar performance with B. sphaericus (Figure 2). Mean mortality of C. quinquefasciatus larvae only remained high in the first two dilutions of the 
Mean mortality rate for Culex quinquefasciatus and Aedes aegypti L4 larvae using Bacillus sphaericus bioinsecticide (strain 2362) produced with white soybean medium. Vertical bars indicate $95 \%$ confidence interval.

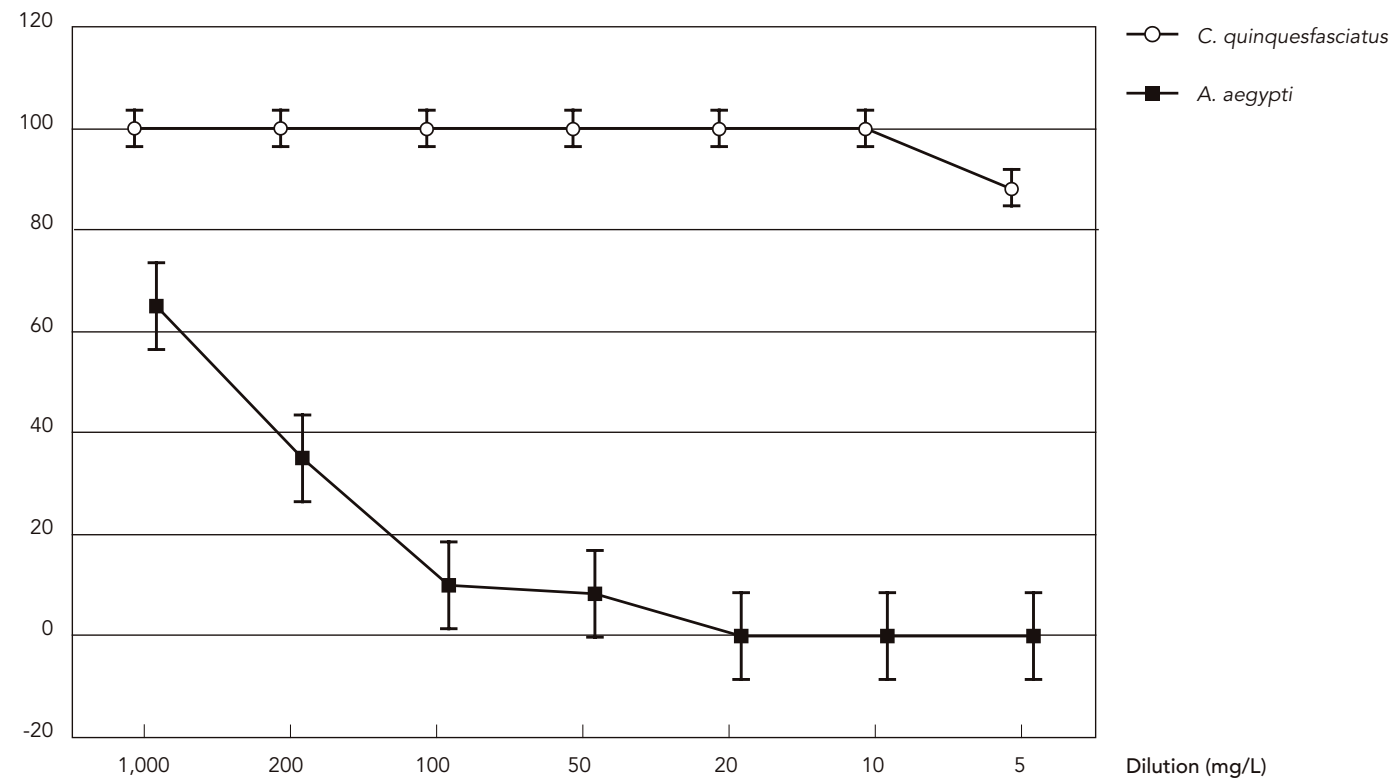

product, $10 \mathrm{mg} / \mathrm{L}$ and $4 \mathrm{mg} / \mathrm{L}$. At a concentration of $2 \mathrm{mg} / \mathrm{L}$, we observed a drop in the bioinsecticide's toxicity, resulting in a mean mortality of $40.4 \%$, which decreased even further until practically disappearing at $1 \mathrm{mg} / \mathrm{L}$. $\mathrm{LD}_{50}$ and $\mathrm{LD}_{90}$ for the $B$. sphaericus bioinsecticide produced with the LB medium were $2.43 \mathrm{mg} / \mathrm{L}$ and $4.37 \mathrm{mg} / \mathrm{L}$, respectively.

The difference in the bioinsecticides' efficiency indicates better fermentation of B. sphaericus in the white soybean medium and thus higher production of endotoxin. This could be explained by the characteristics of the microorganism and the substrates present in the culture media. $B$.

\section{Table 1}

Toxicity of Bacillus sphaericus bioinsecticide (strain 2362) produced with white soybean meal compared to Luria Bertani (LB) reference medium. Mean values, with maximum and minimum values in parentheses.

\begin{tabular}{llll}
\hline Culture medium & $\mathrm{LD}_{50}(\mathrm{mg} / \mathrm{L})$ & $\mathrm{LD}_{90}(\mathrm{mg} / \mathrm{L})$ & $\mathrm{N}$ \\
\hline $\mathrm{LB}$ & $2.43(3.00-2.12)$ & $4.37(5.21-4.10)$ & 6 \\
White soybean meal & $0.90(1.08-0.76)$ & $2.26(2.36-2.00)$ & 6 \\
\hline
\end{tabular}

sphaericus, unlike most microorganisms, does not use sugars in energy metabolism, because the bacteria lacks enzymes that are capable of metabolizing sugars as a source of carbon 22 . Alice et al. ${ }^{23}$ succeeded in recreating this enzymatic function in B. sphaericus by inserting Staphylococcus aureus-specific genes, allowing the use of sugars in the bacterial growth. However, under normal conditions B. sphaericus is unable to process this type of substrate, so sugars are unnecessary in this bacteria's culture media. Poopathi et al. 24 tested a series of compounds for producing $B$. sphaericus and B. thuringiensis var. israelensis, standardizing a composition that used potato broth as the main component. Just as adding sugars is useless in the production of B. sphaericus, starch also proved ineffective in fermentations of this bacteria. Thus, the potato broth culture medium showed mortality results that were merely similar to those obtained with the LB medium. Energy compounds, saccharides, and polysaccharides are completely absent from the white soybean meal medium. On the other hand, the substrate contains high amounts of protein, characteristic of this soybean byproduct. The combination of the two characteristics proved highly favorable to B. sphaericus growth and endotoxin production. 
Mean mortality rate of Culex quinquefasciatus L4 larvae caused by Bacillus sphaericus (strain 2362) cultured in Luria Bertan (LB) and white soybean media. Vertical bars indicate $95 \%$ confidence interval, and asterisks mark significant differences between the media ( $t$ test; $p<0.05$ ).

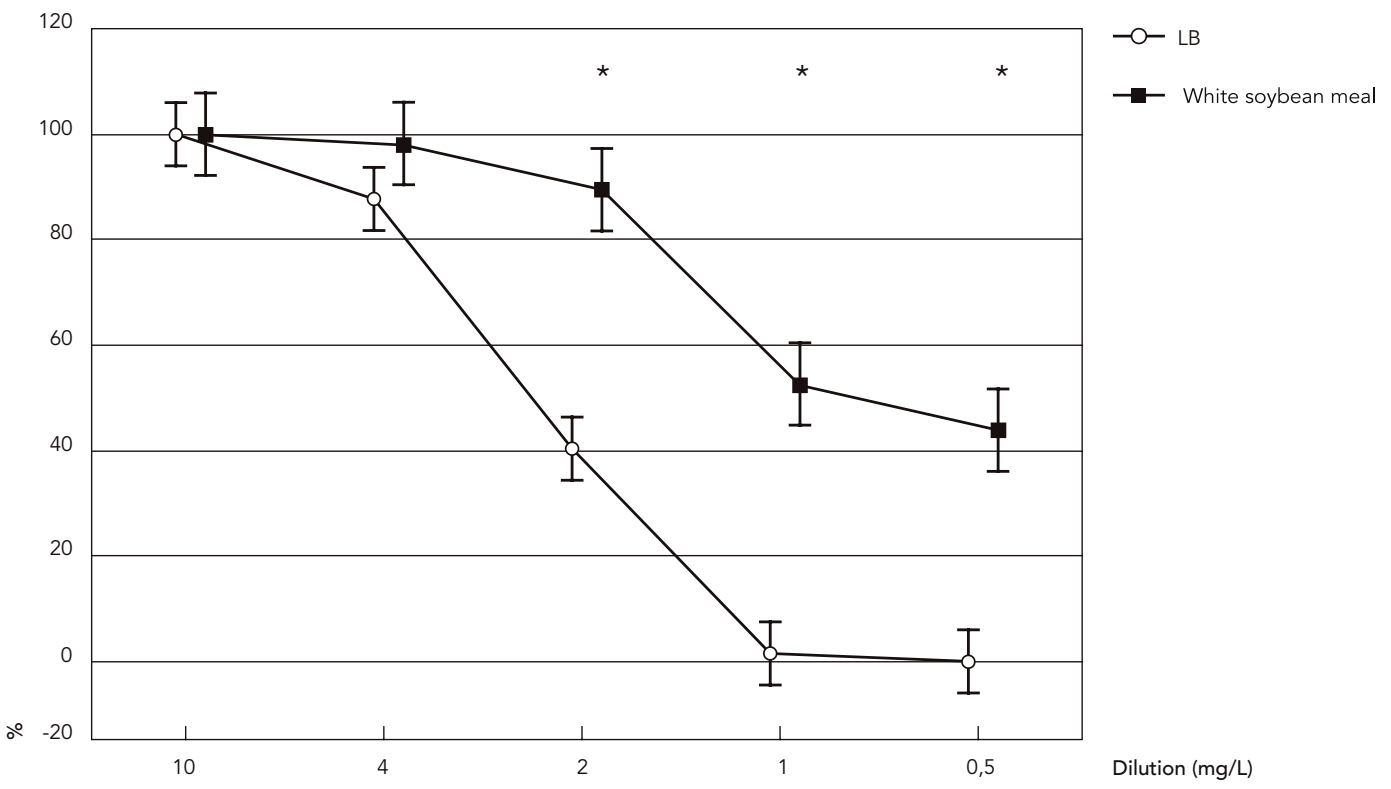

Just as the larval mortality rates clearly favored the bioinsecticide cultured with white soybean meal, the comparison proved even better when the cost of the ingredients was factored in, as shown in Table 2.

The difference in the cost of the two media was extremely disproportional due to the origin of the raw materials. While the LB reference medium is produced from high-cost laboratory substances sold in small amounts, the white soybean medium dispenses with such expensive ingredients. With white soybean meal as the principal component, the final cost is negligible, since this soybean byproduct is used in agribusiness as an animal feed supplement, sold only in bulk amounts. The cost of the raw materials used to produce $1 \mathrm{~L}$ of the bioinsecticide with the LB medium is approximately US\$ 7.87 , while the same amount of medium produced with white soybean meal costs only US\$ 0.07 . The cost ratio for producing the culture medium is thus 1:110 in favor of the new bioinsecticide.

This ratio becomes even more unequal when considering the products' efficiency. Based on $\mathrm{LD}_{90}$, it is estimated that approximately double the amount of product fermented with the LB medium would be needed to equal the mortality rate of the white soybean meal. The cost ratio would thus increase to 1:220.

Table 2

Cost comparison for producing Luria Bertani (LB) medium and white soybean medium.

\begin{tabular}{|c|c|c|c|c|}
\hline Culture medium & Composition & Amounts (g/L) & Final cost (US\$/L) & Cost difference for LD $_{90}$ \\
\hline LB & Peptone + yeast extract + sodium chloride & $10+5+10$ & 7.87 & $1: 220$ \\
\hline White soybean meal & White soybean meal + polyethylene glycol & $40+2$ & 0.07 & - \\
\hline
\end{tabular}




\section{Resumo}

A utilização de bioinseticidas tem se mostrado útil aos programas de prevenção de diversas enfermidades devido a sua especificidade e eficiência contra insetos vetores. No presente trabalho, o bioinseticida de Bacillus sphaericus foi produzido com um meio de cultivo composto de farelo branco de soja e aplicado em larvas de Culex quinquefasciatus, espécie suscetível, e Aedes aegypti, espécie refratária, usada como controle negativo. O desempenho foi comparado com o do produto fermentado com o meio referência $\mathrm{Lu}$ ria Bertani (LB). Os experimentos constataram que $\mathrm{C}$. quinquefasciatus apresentou uma alta suscetibilidade ao produto produzido com farelo branco de soja, alcançando mortalidade de $100 \%$ mesmo na diluição de $10 \mathrm{mg} / \mathrm{L}$, enquanto A. aegypti não atingiu $70 \%$ na concentração de $1 \mathrm{~g} / \mathrm{L}$. Quando comparado com o meio referência, a formulação proposta proporcionou um alto poder larvicida, alcançando uma $D L_{90}$ de 2,26mg/L, ao passo que LB precisou de 4,37 mg/L para a mesma mortalidade. A comparação do custo das formulações favoreceu o bioinseticida produzido com o meio farelo branco de soja. Considerando os valores de $D L_{90}$, a relação do custo das matérias-primas ficou próxima de 1:220.

Inseticidas; Controle de Vetores; Soja

\section{Contributors}

A. L. A. Melo participated in the literature review, methodology, analysis of the results, and writing of the final article. C. R. Soccol collaborated in the methodology and analysis of the results. V. Thomaz-Soccol contributed to the literature review and analysis of the results. M. Nogueira Jr. contributed to the statistical analysis of the results.

\section{References}

1. Smith TA, Leuenberger R, Lengeler C. Child mortality and malaria transmission intensity in Africa. Trends Parasitol 2001; 17:145-9.

2. Casali CG, Pereira MRR, Santos LMJG, Passos MNP, Fortes BPMD, Valencia LIO, et al. A epidemia de dengue/dengue hemorrágico no município do Rio de Janeiro, 2001/2002. Rev Soc Bras Med Trop 2004; 37:296-9.

3. Spielman A, Andreadis TG, Apperson CS. Outbreak of West Nile virus in North America. Science 2004; 306:1473-5.

4. Consoli RAGB, Oliveira RL. Principais mosquitos de interesse médico. Rio de Janeiro: Editora Fiocruz; 1994.

5. Franco O. A história da febre amarela no Brasil. Rio de Janeiro: Superintendência de Campanhas de Saúde Pública/Brasília: Ministério da Saúde; 1969.

6. Hayes SM. 20th-century insect control. Agricultural Research 1992; 40:4-9.
7. Macoris MLG, Andrighetti MTM, Takaku L, Glasser CM, Garbeloto VC, Cirino VCB. Alteração de resposta de suscetibilidade de Aedes aegypti a inseticidas organofosforados em municípios do Estado de São Paulo, Brasil. Rev Saúde Pública 1999; 33:521-2.

8. Bracco JE, Dalbon M, Marinotti O, Barata JMS. Resistência a inseticidas organofosforados e carbamatos em população de Culex quinquefasciatus. Rev Saúde Pública 1997; 31:182-3.

9. Kumar A, Sra K, Sangodkar UMX, Sharma VP. Advances in the bio-control of mosquito vectors utilising Bacillus sphaericus and B. thuringiensis var. israelensis. Proceedings of the National Academy of Sciences India 2000; 70:1-20.

10. World Health Organization. Report of informal consultation of the development of B. sphaericus as a microbial larvicide. Geneva: World Health Organization; 2002. 
11. Davidson EW. Binding of the Bacillus sphaericus (Eubacteriales: Bacillaceae) toxin to midgut cells of mosquito (Diptera: Culicidae) larvae: relationship to host range. J Med Entomol 1988; 25:151-7.

12. Brown MD, Watson TM, Carter J, Purdie DM, Kay BH. Toxicity of VectoLex (Bacillus sphaericus) products to selected Australian mosquito and nontarget species. J Econ Entomol 2004; 97:51-8.

13. Ganushkina LA, Lebedeva NN, Azizbekian RR, Sergiev VP. The duration of the larvicidal effects of spore crystalline mass of the bacteria Bacillus sphaericus spp. israelensis and Bacillus sphaericus in the laboratory setting. Med Parazitol (Mosk) 2000; (4):25-9.

14. Castro SD, Colombi E, Flores LN, Canales D. Aplicación del biolarvicida Bacillus sphaericus-2362 (GRISELESF) para el control de la malaria en un área de salud de la República de Honduras. Rev Cubana Med Trop 2002; 54:134-41.

15. Bhumiratana A. Local production of Bacillus sphaericus. In: Sutherland A, Barjac H, editors. Bacterial control of mosquitoes and black flies. New Jersey: Rutgers University Press; 1991. p. 272-83.

16. Obeta JAN, Okafor N. Production of Bacillus sphaericus strain 1593 primary powder on media made from locally obtainable Nigerian agricultural products. Can J Microbiol 1983; 29:704-9.

17. Vandekar M, Dulmage HT. Guidelines for the production of Bacillus thuringiensis H-14. Geneva: United Nations Development Programme/WHO Special Programme for Research and Training in Tropical Diseases/World Bank; 1982.
18. Arcas J, Yantorno O, Ertol R. A new medium for growth and delta-endotoxin production by $\mathrm{Ba}$ cillus thuringiensis var. kurstaki. Biotechnol Lett 1984; 6:495-500.

19. Sambrook J, Fritsch EF, Maniatis T. Molecular cloning: a laboratory manual and edition. New York: Cold Spring Harbor Laboratory; 1989.

20. World Health Organization. Bioassay method for the titration of Bacillus sphaericus preparations with RB standard. Informal consultations on the development of Bacillus sphaericus as a microbial larvicide. Geneva: World Health Organization; 1985.

21. Abbott WS. A method of computing the effectiveness of an insecticide. J Econ Entomol 1925; 18:265-6.

22. Hui YH, Khachatourians GG. Food biotechnology microorganisms. New York: VHC Publishers; 1994.

23. Alice AF, Perez-Martinez G, Sanchez-Rivas C. Phosphoenolpyruvate phosphotransferase system and N-acetylglucosamine metabolism in Bacillus sphaericus. Microbiology 2003; 147(Pt 7):1687-98.

24. Poopathi S, Kumar KA, Kabilan L, Sekar V. Development of low-cost media for the culture of mosquito larvicides, Bacillus sphaericus and Bacillus thuringiensis serovar. israelensis. World J Microbiol Biotechnol 2002; 18:209-16.

Submitted on $17 / \mathrm{Jul} / 2007$

Final version resubmitted on $08 / \mathrm{Jan} / 2008$

Approved on 17/Jan/2008 